\title{
Social media promotions and travelers' value-creating behaviors: The role of perceived support
}

\author{
LUIS V. CASALÓ (Universidad de Zaragoza, lcasalo@unizar.es), JAIME ROMERO
}

(Universidad Autónoma de Madrid, jaime.romero@uam.es)

\begin{abstract}
:
Purpose-Encouraging travelers to create value that benefits firms is of great relevance for companies that operate in online contexts. This study focuses on online travel agencies to investigate how monetary promotions (i.e., economic incentives) and nonmonetary promotions (i.e., draws and contests) conducted through social media enhance customers' voluntary behaviors (i.e., suggestions, word of mouth, and social media interactions) that go beyond brand choice, which may provide benefit to firms.

Design/methodology/approach-The research model draws on social exchange theory, equity theory, and the concept of perceived support -how customers perceive that companies care about their well-being. The authors collect information from 491 users of online travel agencies in Spain and test their hypotheses using partial least squares. They also evaluate the existence of indirect effects.
\end{abstract}

Findings - Promotions developed by companies make customers more likely to perform, voluntarily, the helping behaviors of suggestions, word of mouth, and social media interactions, through the influence of perceived support.

Research limitations/implications-Use of a single survey to collect measures and restriction of the sample to Spanish-speaking travelers suggest caution in generalizing the results. Future research could investigate other company-initiated actions and other value-creating behaviors of travelers.

Practical implications-Promotions help develop perceived support for customers, which leads to voluntary, valuable traveler behaviors. Promotions may be also sufficient to trigger some customer behaviors, such as word-of-mouth.

Originality/value-Based on social exchange and equity theories, this paper investigates the influence of social media promotions on customers' voluntary behaviors via perceived support. 


\section{Introduction}

Travel companies have traditionally sought customer behaviors that benefit their firms. Travelers' suggestions can be vital sources of information (e.g., Bartkus et al., 2009) and influence others’ perceptions via word-of-mouth (WOM) (e.g., Casaló et al., 2010). Therefore, firms capitalizing on the talents of their customers and including them as potential partners may incur competitive advantages over other firms (Bettencourt, 1997).

For this reason, companies engage in some promotions that not only aim to increase sales but also show customers that companies care for their well-being. Responding to such company support, customers may create value for companies (e.g., Keh and Teo, 2001). The emergence of social media is creating a new context where companies can distribute their promotions (e.g., Christou, 2011) and customers can develop new value-creating behaviors (Hassan and Casaló, 2016). Many companies in the travel and hospitality industry already involve their customers in creating value through social media. For example, Starbucks has successfully developed a social network that involves customers in new-service development (Sigala, 2012). Many online travel agencies (OTAs) — the focus of this study — include travelers' generated content (e.g., evaluations and reviews of hotels or restaurants) in their services. They even develop content (e.g., best/worst hotel lists) using information provided by travelers (Casaló et al., 2015).

Previous research on travel industry promotions has not clarified the impact of such promotions on these voluntary behaviors. Consistent with promotion literature in other fields, previous research has focused on the effect of promotions on sales (Yi and Yoo, 2011). Moreover, most research has been conducted in the offline context (e.g., Ellerbrock, 1981; Pennington-Gray et al., 2002). More recent research, conducted in the 
online context, tends to focus on the role of monetary promotions (e.g., Sigala, 2013; Zhao et al., 2014), despite the increasing relevance of non-monetary offerings (Yi and Yoo, 2011). Furthermore, research on social media in the travel industry focuses on the fields of information search, website analysis, and internet marketing (Standing et al., 2014); it has not studied how promotions enhance voluntary behaviors.

Prompting travelers to create value, and benefiting from the value they create, is very important for travel companies such as OTAs because of the increasing importance of such agencies (e.g., Inversini and Masiero, 2014), the intense competition among them, and their growing use of social media (e.g., Casaló, 2008). However, these companies lack understanding of how their social media promotions-both monetary and non-monetary-increase voluntary, helpful customer behaviors. By using the concept of perceived support, we aim to shed light on this issue. We adopt equity theory (Adams, 1965) and social exchange theory (Blau, 1964) to show that promotions can motivate value-creating traveler behaviors through their effect on perceived support.

Our study contributes to the field by investigating (1) the relevance of OTA-driven monetary and non-monetary online promotions, using social media to support customers, and (2) some of the consequences of perceived support in terms of valuecreating behaviors. We focus on two online promotions for which companies use social media: economic incentives (monetary promotions), and draws and contests (nonmonetary promotions) (Gutierrez et al., 2017). Whereas previous studies have well analyzed the first type of promotions, the second type has received minimal research attention (Yi and Yoo, 2011). We also consider three customer behaviors that can create value for firms in the context of business-to-customer relationships. These behaviors include customers’ suggestions (e.g., van Doorn et al., 2010), WOM (e.g., Romero, 2017), and social media interactions (e.g., Gutierrez et al., 2017). These behaviors are 
very relevant for travel and hospitality firms. Customers' suggestions are an important element of service management (e.g., Bartkus et al., 2009) that can improve current services or lead to new services (Romero, 2017). Positive WOM (recommendations of company products and services to other customers by existing customers) is crucial because of the intangible nature of travel services (e.g., Litvin et al., 2008). Finally, social media interactions strengthen the bonds between travelers and companies (Casaló, 2008). In this study, we assume that (1) suggestion-making and WOM can take place either online or offline and (2) social media interactions refers to any interaction behavior of a consumer through social media related to OTAs (e.g., commenting on OTAs’ official profiles or about OTA products, sharing OTA content, following OTA official profiles). Hence, we investigate the influence of monetary and non-monetary online promotions by OTAs on customers’ voluntary behaviors via perceived support.

\section{Theoretical background and formulation of hypotheses}

\subsection{Monetary and non-monetary online promotions in the travel industry}

The existing literature draws great attention to sales promotions because of their potential influence on consumer behavior. Previous studies identify various types of promotions (Yi and Yoo, 2011). Monetary promotions — that is, price-oriented promotions - are the most popular and attract more research attention (Christou, 2011; Sinha and Smith, 2000). Monetary promotions include, among others, coupons, price reductions, and discounts (Chandon et al., 2000). However, research interest in nonmonetary (non-price-oriented) promotions (e.g., Yi and Yoo, 2011), including gifts, contests, and sweepstakes (Chandon et al., 2000), is increasing.

Using sales promotions in the travel and hospitality industry is widespread and has great practical relevance (Park and Gretzel, 2011), even though traditional research 
focuses on monetary promotions such as coupons (e.g., Ellerbrock, 1981) or discounts (e.g., Pennington-Gray et al., 2002). More recently, the internet and social media have emerged as new methods of distributing sales promotions, and some authors have investigated various types of online promotions developed by travel companies (e.g., Christou, 2011; Sigala, 2013; Zhao et al., 2014; Crespo and Del Barrio, 2016). Most focus on monetary promotions, given that new information and communication technologies allow improved targeting of monetary promotions (DelVecchio, 2005). Zhao et al. (2014) analyze the influence of online coupons on service recovery, and Sigala (2013) investigates how tourism firms must design and implement online coupons. In an attempt to enhance understanding of this new phenomenon, Christou (2011) analyzes customers' sensitivity to two online promotional techniques used by hotels (i.e., extra points and price discounts) and examines customers' attitudes to promotional deals in general, finding that they have a positive effect on purchase intentions of products promoted online. Crespo and Del Barrio (2016) focus on the air transport industry to compare the influence of monetary and non-monetary online promotions on airline ticket purchasing; they conclude that users' experiences influence promotions' effectiveness (novice internet users prefer discounts, whereas expert users are more influenced by non-monetary promotions). However, the volume of research on the effects of non-monetary promotions by OTAs remains minimal, even though many agencies are already running specific, contest-based promotions such as prizes for the best blogs or the best holiday photos (Schmalleger and Carson, 2008).

Furthermore, because existing literature focuses on the use of sales promotions to increase sales directly, researchers tend to analyze either the promotion/sales relationship (Yi and Yoo, 2011) or the influence of sales promotions on consumer behavioral intentions (Christou, 2011). However, the influence of promotions may go 
beyond sales; authors argue they can also alter consumer perceptions of brands (Hunt and Keaveney, 1994) and attitudes (Crespo and Del Barrio, 2015), which in turn may influence behaviors other than brand choice. Accordingly, we attempt to shed light on the influence of monetary and non-monetary promotions, developed by OTAs, on voluntary consumer behaviors that benefit companies by increasing the perceived support for customers.

\subsection{Perceived support for customers}

We define perceived support for customers as customers’ perceptions of the extent to which companies value them and care about their well-being (Bettencourt, 1997). Specifically, this variable is an adaptation, in the context of the company/customer relationships, of the concept of perceived organizational support for employees proposed by organizational support theory (e.g., Eisenberger et al., 1986).

Our interest in this variable stems from the finding that perceived support signals a firm's commitment to their customers, making them more willing to cooperate with firms in exchange; according to Kurtessis et al. (2015), it is strongly associated with affective and attitudinal outcomes. Customers conduct voluntary helping behaviors that are beneficial for companies but are not formally required (e.g., Rosenbaum and Massiah, 2007). They perform these behaviors at their discretion and go beyond loyalty or other compulsory behaviors required by service delivery (e.g., Keh and Teo, 2001). This "extra-role” of spontaneous and voluntary performance occurs in various contexts, such as perceived organizational support for employees (e.g., Kurtessis et al., 2015) and perceived support among customers (Rosenbaum and Massiah, 2007).

Given that service literature suggests the relevance of perceived support for customers (e.g., Adelman and Ahuvia, 1995), it is important to investigate which OTA 
promotions can increase this support. Such knowledge is crucial for companies seeking to benefit from travelers' helping behaviors.

\subsection{Research hypotheses}

Perceived support for customers may arise from company behaviors such as maintaining fairness in interpersonal treatment, having effective recovery, keeping promises, providing reliable service, and responding to special requests (e.g., Parasuraman et al., 1985; Bitner et al., 1990). Perceived support develops when organizations offer tangible benefits and social resources (Kurtessis et al., 2015). Companies usually offer these benefits to their customers via promotions; monetary promotions offer economic benefits such as monetary savings, and non-monetary promotions help communicate emotional benefits such as opportunities for selfexpression or entertainment. However, most previous studies focus on the offline context, even though the increasing use of internet and social media provides companies with a new platform on which they may develop online promotions to support their customers.

Our work focuses on organized draws and contests (non-monetary promotions), as well as the offering of economic incentives (monetary promotions) (Gutierrez et al., 2016), which are two of the most relevant online promotions conducted by companies in the social media context. According to Hennig-Thurau et al. (2004), customers tend to view these rewards as signs of companies' appreciation. Since perceived support for customers is the result of customers' beliefs that firms truly care about them (Bettencourt, 1997), the incentives we consider in this study -particularly their attractiveness to customers- may drive perceived support. That is, the more each type of 
promotion (either monetary or nonmonetary) attracts a customer, the greater the perceived support. Focusing on OTAs, we propose the following:

H1: The attractiveness of draws and contests organized by OTAs and conducted in social media has a positive effect on perceived support for customers.

H2: The attractiveness of economic incentives offered by OTAs in social media has a positive effect on perceived support for customers.

Equity theory (Adams, 1965) and the social exchange perspective (Blau, 1964) offer suitable frameworks to explain why travelers may perform behaviors that create value for firms. First, equity theory addresses how people act upon the perception of inequity in a relationship (Steenhaut and Van Kenhove, 2005). According to these authors, inequity in customer-company relationships exists when the perceived inputs (contributions to relationships) and outcomes (benefits obtained) are significantly different. Thus, if customers perceive that company support increases, they benefit from an imbalance in that relationship. To correct this imbalance, customers feel obliged to reciprocate; they try to restore equity by behaving advantageously for the company. Such equity motivations may explain customers' decisions to perform behaviors that benefit firms, such as providing online reviews in web-based opinion platforms (e.g., Hennig-Thurau et al., 2004).

Similarly, social exchange theory explains voluntary actions that go beyond obligations in relationships (Blau, 1964), such as customer behaviors that transcend mere economic duties. It suggests that customers are more likely to develop behaviors that benefit firms if they believe the firms value them and treat them fairly and in a responsible manner (e.g., Bettencourt, 1997), that is, when they perceive company support. According to previous research in the organizational context and in businessto-customer relationships (e.g., Eisenberger et al., 1990), customers who perceive 
company support may reciprocate with behaviors that generate value for firms. When customers believe that organizations care about them, they feel obliged to help the organizations by developing loyal or cooperative behaviors that create value for firms (Bettencourt, 1997).

Following the existing literature, we consider three customer behaviors that can create value for OTAs due to perceived support: suggestions, WOM, and social media interactions. First, for companies, customers are a crucial source of information that may help improve OTAs’ products and services; their suggestions may even lead to the development of new products and services (Romero, 2017). Previous studies note the relevance of customers’ suggestions for management in the hospitality industry (e.g., Bartkus et al., 2009).

Second, by contributing to WOM, travelers may become promoters of OTAs' products and services (e.g., Casaló, 2008). WOM is valuable because customers go beyond their own interests to promote the organizations’ interests; WOM has an impact on firms’ images (Parasuraman et al., 1985) and on other customers' decisions (Kozinets, 2002). Given that travelers cannot evaluate OTAs’ services before purchase due to their intangibility (Litvin et al., 2008), the importance of WOM increases (Confente, 2015); WOM becomes an important source of information for travelers when they make travel decisions (Bieger and Laesser, 2004).

Finally, in addition to promoting OTAs overall, social media interactions can motivate travelers to generate online content about companies (e.g., Casaló, 2008). Customers develop stronger affective bonds because of their greater contact with companies through social networking profiles (e.g., Gutierrez et al., 2016), leading to greater intentions to buy OTAs’ products and services (e.g., Casaló, 2010). Accordingly, we propose the following: 
H3: Perceived support for customers has a positive effect on customers' suggestions.

H4: Perceived support for customers has a positive effect on customers' WOM. H5: Perceived support for customers has a positive effect on customers' social media interactions.

\section{Methodology}

\subsection{Research design}

We employed a questionnaire to collect data on the variables included in the hypotheses. The target population of our study was users of OTAs. Particularly, we focused on two agencies - Logitravel and Atrápalo—-that allow users to contribute to their company blogs and online communities and hold social network accounts (e.g., on Facebook and Twitter). These agencies employ both monetary and non-monetary promotions; that is, they offer economic incentives to customers and organize draws and contests.

We measured the variables in our study using multi-item scales. Hence, we evaluated two models. First, we assessed the reliability and validity of the constructs, that is, of our measurement model. Second, we analyzed the direct and indirect relationships among the latent variables; therefore, structural equation modeling was an appropriate technique for our research purposes (e.g., Davcik, 2014).

\subsection{Data collection}

We collected our data through a web-based survey. We asked participants to answer questions about the travel agency they use most. Specifically, participants completed a questionnaire that included multiple-item reflective measurement scales 
inspired by existing literature (Table 1). To ensure the content validity of scales and confirm that the adaptations to our research context were correct, we followed Zaichkowsky’s (1985) method and asked a panel of 10 experts in tourism, e-commerce, and marketing to classify each item regarding its relevance and its representativeness of its corresponding construct. We retained only items producing a high level of consensus among the experts as part of the final scales.

This process allowed us to collect data from 491 users of OTAs in Spain. Participants represented demographic groups that were representative of those that employ the internet for travel and accommodation purposes in Spain $(47.42 \%$ of the respondents are women and 52.58\% are men vs. $48.06 \%$ and $51.94 \%$ in the population; $15.24 \%$ of the respondents are $16-44$ years old vs. $15.74 \%$; $29.18 \%$ are $25-34$ years old vs. $29.34 \%$; $27.04 \%$ are $35-44$ years old vs. $26.43 \%$; $17.60 \%$ are $45-55$ years old vs. 17.74\%; and 10.94\% are older than 55 years vs 10.66\%; INE, 2012)

\subsection{Assessment of common method bias}

Using a single survey to collect data may cause problems related to common method bias. To prevent this potential problem, we first took into account procedural recommendations to minimize common method bias through study design (Podsakoff et al., 2003). We assured that participants’ responses would remain confidential and specifically stated that there were no right or wrong answers. We also guaranteed their anonymity to avoid dishonest answers. Furthermore, although the data came from the same sources with no temporal separation, we designed the questionnaire to avoid any direct connection between dependent and independent variables; we induced a psychological disconnection by including questions unrelated to the research objective 
(e.g., the frequency of access to social networking sites, sites most often visited).

Accordingly, participants could not infer any cause-effect between variables.

Second, evidence of common method bias may have also resulted in extremely high correlations, that is, greater than .90 (Pavlou et al., 2007). As Table 2 shows, given that correlations were below this critical threshold, common method bias was not a major concern according to this criterion.

Finally, we assessed common method bias statistically, following Liang et al.'s (2007) test. This method is commonly used in tourism research (e.g., Lo et al., 2017) and in other areas. However, we evaluate the test's results purely as an extra assessment of common method bias, given that the method has sometimes been criticized (Chin et al. 2012). Specifically, we included a common method factor with all items in a model that incorporated the constructs considered in this research. Next, we calculated the variance of each item explained by its corresponding substantive construct and by the common method factor. On average, the common method factor determined less than $2 \%$ of the indicators' variance.

Taking this evidence together, we concluded that common method bias was not a major concern in this study.

\subsection{Measures validation}

We used partial least squares (PLS) as the estimation procedure; PLS can handle data without multivariate normality better than covariance-based structural equation models, which assume data normality. We employed SmartPLS 3.0 (Ringle et al., 2015) and used consistent PLS because it solves potential inconsistency problems of traditional PLS (Dijkstra and Henseler, 2015), which can lead to wrong path estimates and construct measures. Additionally, our sample consisted of 491 participants, thereby 
meeting the sample size requirements of PLS (10 observations multiplied by the maximum between the construct that has the highest number of indicators or the endogenous construct with the largest number of exogenous constructs) (Davcik, 2014). In our case, perceived support for customers had 14 indicators, hence requiring a minimum sample size of 140 .

We evaluated the reliability and the convergent and discriminant validity of our variables (Table 1). Loadings of all indicators were above .70. Composite reliability varied between .75 and .91. Cronbach’s alphas ranged between .75 and .97; all above the .7 cutoff value proposed by Nunnally (1978). The average variance extracted (AVE) varied between .60 and .88 , all above the .50 cutoff value suggested by Fornell and Larcker (1981).

\section{INSERT TABLE 1 ABOUT HERE}

To evaluate the discriminant validity, we first applied the Fornell and Larcker (1981) criterion, by which the square root of the AVE of a construct must exceed its correlations with other constructs. Second, we assessed the heterotrait-monotrait ratio (HTMT) of the correlations, which is more sensitive to a lack of discriminant validity than other criteria (Henseler et al., 2015). To indicate discriminant validity, the HTMT between two constructs must be lower than .85. Both criteria supported the discriminant validity of our constructs (Table 2).

\section{INSERT TABLE 2 ABOUT HERE}

\section{Results}

Once we had validated the measures, we developed a structural equation model (see Figure 1) that gave support to our five hypotheses and achieved acceptable values 
of model fit. We report path coefficients, $\mathrm{R}^{2}$ of endogenous variables, effect sizes, and the predictive relevance of our model (Hair et al. 2017, Chin, 2010).

All path estimates in our model were significant at 99\%, according to a nonparametric bootstrap with 10,000 subsamples (no sign change). Additionally, we calculated bias-corrected and accelerated confidence intervals for each parameter. The results from this test were identical; however, for the sake of brevity, we show significance levels only (the confidence intervals are available from the authors upon request). Specifically, both the attractiveness of draws and contests $(\beta=.42, p<.01)$ and of economic incentives $(\beta=.26, p<.01)$ are positively associated with perceived support. Similarly, perceived support is positively associated with the three valuecreating behaviors included in this study, that is, customers' suggestions ( $\beta=.62, p<$ $.01)$, WOM $(\beta=.67, p<.01)$, and social media interactions $(\beta=.62, p<.01)$. Given these relationships, this model allows us to explain, in part, our dependent variables. The adjusted $\mathrm{R}^{2}$ of perceived support, customers' suggestions, WOM, and social media interactions are .42, .39, .45 and .39, respectively, showing a moderate fit (Chin, 1998).

Figure 1 also shows the effect sizes. According to Cohen (1998), the effect sizes of draws and contests and economic incentives on perceived support are weak. In contrast, the effect sizes of perceived support on the three online creating behaviors are strong.

Finally, we evaluated the out-of-sample predictive power of our model. The cross-validated redundancy $\mathrm{Q}^{2}$ of perceived support, customer' suggestions, WOM and social interaction are, respectively, .25, .24, .32, and .24. The cross-validated communality measures of these variables are .61, .59, .70 and .58, respectively. Hence, our results support the predictive relevance of our model (Hair et al., 2017). 
In the next section, we further analyze possible indirect or mediated effects to gain extra insights regarding the impact of monetary (economic incentives) and nonmonetary promotions (draws and contests) on customers’ suggestions, WOM, and social media interactions.

\section{INSERT FIGURE 1 ABOUT HERE}

\subsection{Post hoc analyses of indirect effects}

According to our results, draws and contests and economic incentives that OTAs offer may have an indirect or mediated effect on customers' suggestions, WOM, and social interactions. We posited that perceived support could mediate the effects of these actions. Accordingly, we analyzed these potentially mediated relationships. We followed Chin (2010) and Zhao et al. (2010) to calculate bias-corrected and accelerated confidence intervals of such effects. This method is common in tourism research (e.g., Matzler et al. 2016). The indirect effect of an independent variable on a dependent variable in each sample is measured as the product of the effect of the independent variable on the mediating variable by the effect of the mediating variable on the dependent variable. The indirect effects in each sample are used to build confidence intervals. If the intervals exclude the value 0 , the indirect effects are significant. In our study, we used 10,000 subsamples, with no sign change. Table 3 shows the results of our analyses.

This estimation indicates that the attractiveness of draws and contests organized by OTAs indirectly influences customers' suggestions to companies (confidence interval: .15-.37), WOM (.17-.39) and social media interactions (.24-.57). Similarly, the attractiveness of economic incentives indirectly influences these variables (.15-.37, $.06-.29$ and .06-.31, respectively). The existence of these indirect effects constitutes 
sufficient evidence of mediated relationships (Zhao et al., 2010). Therefore, we can conclude that perceived support mediates the impact of these two online promotions on customers’ suggestions, WOM, and social media interactions.

Following Matzler et al. (2016), we also examined the direct effects of draws and contests and economic incentives on customers' suggestions, WOM, and social media interactions. For this purpose, we estimated an extended version of our research model, which also included these direct effects. Although these effects were outside the scope of our model, further analysis allowed us to gain extra insights into the mediated relationships in our model.

\section{INSERT TABLE 3 ABOUT HERE}

Table 3 shows the estimation results for our extended research model. The results reveal two types of mediation relationships in our model. On one hand, some direct effects are not significant, thus indicating indirect-only effects (Zhao et al., 2010); this is the case for the impact of draws and contests on WOM and of economic incentives on customers' suggestions and social media interactions. On the other hand, the direct effects of draws and contests on customers' suggestions and social media interactions, as well as of economic incentives on WOM, are significant and positive. This indicates complementary mediations in these three cases (Zhao et al. 2010). Complementary mediations point to the existence of some omitted second mediators that future researchers could pursue. We discuss this issue in the next section.

\section{Discussion and Conclusions}

\subsection{Conclusions}

Company promotional actions can enhance customers' voluntary behaviors that improve and benefit firms (Rosenbaum and Massiah, 2007). Perceived support for 
customers is a crucial aspect in this regard (e.g., Keh and Teo, 2001). Therefore, by focusing on OTAs, we demonstrate how OTAs’ actions in social media can enhance perceived support that leads customers to perform helping behaviors that are not required by companies.

Regarding monetary and non-monetary online promotions as antecedent factors, our findings suggest that companies can increase perceived support for travelers through two types of social media promotions: economic incentives and draws and contests. These results are consistent with previous literature showing that perceived support for customers may result from company actions (e.g., Parasuraman et al., 1985; Bitner et al., 1990) that offer tangible benefits and social resources (Kurtessis et al., 2015). Our results are also consistent with previous research focusing on OTAs, which find that promotions -mainly monetary ones- have positive consequences, for instance, on service recovery (Zhao et al., 2014) or buying intentions (Christou, 2011). Our results also suggest a greater influence of non-monetary promotions (draws and contests) on perceived support. This in line with previous research that suggests that expert users are more sensitive to non-monetary promotions (Crespo and Del Barrio, 2016). Given OTAs penetration in Spain, our sample may mainly include experienced users, thus explaining this finding.

We also find that perceived support positively influences making suggestions, WOM, and social media interactions. Although previous studies on OTAs have not analyzed these relationships, our results are consistent with previous research in the offline environment and organizational contexts (e.g., Eisenberger et al., 1990). They confirm that travelers reciprocate by helping OTAs with behaviors that, although unrequested, generate value for the companies. 
Finally, our findings suggest that perceived support partially or fully mediates the influence of monetary and non-monetary promotions in social media on customers' voluntary helping behaviors, which highlights the relevant role of perceived support in causing travelers to cooperate with OTAs. This is also in line with previous studies suggesting that the influence of promotions goes beyond behavior and choices, also affecting customers’ perceptions (Hunt and Keaveney, 1994) and attitudes (Crespo and Del Barrio, 2015). However, promotions may be sufficient to trigger customer behavior in some cases. For example, our results suggest that the direct effect linking economic incentives to WOM is especially strong, which is predictable given that WOM is a behavior that requires less effort for customers than providing suggestions to the OTA or interacting through social media.

\subsection{Theoretical implications}

Concerning theory, our work confirms the role of customers as sources of value for companies. It adds to the findings of previous studies in the following ways: First, it draws attention to the travel sector by analyzing the role of perceived support for customers in motivating behaviors that create value for OTAs, even when such behaviors are not formally required. In line with previous studies in the service domain (e.g., Adelman and Ahuvia, 1995), it confirms that OTAs can obtain customer voluntary helping behaviors that benefit their firms (i.e., suggestions, WOM, and social media interactions) in return for their support of customers. However, the relevance of perceived support may be greater or lower depending on the type of promotion and the subsequent customer behavior considered, as in some cases, promotions may be sufficient to trigger customer behaviors.

Second, our study focuses on the role of both monetary (i.e., economic incentives) and non-monetary (i.e., draws and contests) promotions in social media to 
increase perceived support for customers. To our knowledge, this is one of the first studies to use the online context to examine the influence of both types of promotions on consumer perceptions of companies (i.e., perceived support) and voluntary behaviors for matters other than brand choice; most previous studies have focused on monetary promotions, operated in the offline context, and examined their influence on sales (e.g., Yi and Yoo, 2011). In sum, our findings suggest that perceived support makes customers behave in ways that benefit companies; companies can develop perceived support by conducting various types of promotion using social media.

\subsection{Practical Implications}

These results offer interesting implications for the management of OTAs. They identify types of company promotions in social media that support travelers and stimulate them to help firms voluntarily.

First, we show that non-monetary promotions such as draws and contests in social media are good ways to develop perceived support for customers. This is not surprising, given that many OTAs are already implementing such promotions using social media (especially on their Facebook fan pages) to increase traveler participation. For example, it is quite normal to find contests such as "win a free trip around the world" or "win an all-inclusive trip for two"-for which travelers must like/comment/share a company publication to participate. Nevertheless, they imply a passive participation; travelers are not required to generate content. To increase the benefits of these actions for firms, we suggest that they develop contests in which travelers are required to create content, such as "best travel photos," "build your own round-the-world trip” or “design your ideal trip.” In these cases, travelers must upload their photos or explain their travel preferences or desired destinations; such 
requirements not only generate feelings of perceived support but also help companies obtain useful information about travelers’ preferences (e.g., Casaló, 2008). Many OTAs also have integrated review systems into their websites; accordingly, companies could develop “best reviewer awards” to recognize their customers’ efforts to voluntarily contribute to their platforms by telling others about their hotel or destination experiences. By improving the personal reputations of winners, this type of recognition could act as a crucial motivator to generate content in online contexts (e.g., Wasko and Faraj, 2005). It could encourage travelers to post more reviews, thereby increasing the value of online platforms for other travelers. Our mediation analysis indicates that such initiatives are reasonable because they show that participation in draws and contests directly influences customers’ suggestions and social media interactions as well.

Second, we show that monetary promotions such as economic incentives are useful tools for developing perceived support and attracting new customers; according to our analysis of mediators, there is also a direct effect of economic incentives on WOM. Specifically, this result suggests that an OTA interested in stimulating WOM could use economic incentives without focusing on customer perceived support. In this respect, the internet is an appropriate context to offer economic incentives to travelers, especially when compared to the offline context. As Verhoef et al. (2007) note, customers use the internet to search for good deals; when they find them, customers are motivated to recommend them to others. However, internet-based monetary promotions have a dark side; discounts and price reductions may increase price competition among companies. Moreover, monetary incentives could be used to directly stimulate voluntary behaviors such as writing online reviews. Our results suggest that companies should avoid this practice, given that the influence of monetary promotions on behaviors that imply customer-generated content (social media interactions) is fully mediated by 
perceived support. Customers may feel that their freedom to write reviews is threatened (Magno et al., 2017), leading them to react in opposition to the desired outcome (Algesheimer et al., 2005). With regard to brand performance, traditional research on monetary promotions tends to find positive effects on sales in the short-term but undermining effects over the long-term (e.g., Doob et al., 1969). Similarly, recent studies suggest that monetary promotions negatively influence brand choice and attitude in the long term (Yi and Yoo, 2011). Indeed, the effort may not pay off in the long term if many of the new customers abandon and shift to other competitors after the monetary promotion expires (Reimers and Xie, 2018). Therefore, we recommend that OTAs expand their strategies beyond economic incentives by combining them with other actions, such as draws and contests, to differentiate themselves from other companies and obtain the benefits derived from supporting customers.

\subsection{Limitations and future research}

Despite the interesting results of this work, we acknowledge some research limitations that constitute opportunities for further research. First, we used a single survey to collect the measures; therefore, even though we took various precautions during analysis (such as establishing discriminant validity of constructs) (e.g., Algesheimer et al., 2005), we interpret our findings cautiously. Second, our sample consisted only of Spanishspeaking travelers; to generalize our results, we recommend replicating the study using a more heterogeneous sample of OTAs and participants from different nationalities/ cultures. Indeed, some studies suggest that the drivers of traveler behavior in social media may differ among people from different countries (Wilson et al., 2012).

Future researchers could also analyze other types of promotions, or even other marketing activities, to compare the effectiveness of social media promotions with other 
alternative tools and programs available to travel agencies. For example, the online promotions that we investigated could be compared with offline promotions to determine potential differences in their effectiveness. Although our research finds a significant influence of economic incentives and draws and contests in social media, their effects sizes are weak, suggesting that other actions could be more effective in increasing perceived support for travelers and motivating value-creating behaviors. Further research could also analyze the drivers of promotion attractiveness. Similarly, it would be helpful to focus on other value-creating behaviors of travelers. Customers appear to be using social media to perform new behaviors (such as defending companies from negative comments and complaints from fellow customers) that benefit brands and companies (Hassan and Casaló, 2016). Although we focus on positive WOM, existing studies have shown that customers may consider negative comments (Salehi-Esfahani et al., 2017) or moderate comments (Mudambi and Schuff, 2010) to be more useful. Accordingly, it would be interesting to evaluate whether perceived support for customers helps reduce negative WOM that is highly damaging to companies. Such reduction could help decrease the loss of potential customers.

It is important to note that respondents in our sample could interact with OTAs other than those under study. Therefore, some respondents could have previous experiences with promotions included in our research. Taking into account that more experienced users are more affected by non-monetary promotions (Crespo and Del Barrio, 2016), participants’ previous experiences in this regard could have moderated the relationship between promotions and perceived support. Further research could explore this potential moderating effect by incorporating competition into the analysis. Specifically, it could be useful to analyze the effects of monetary and non-monetary 
promotions considering whether customers interact or not with other OTAs and whether competitors perform these promotions as well.

Finally, as mentioned, the complementary mediations found in our analyses suggest the existence of a second omitted mediator. For instance, satisfaction, as an overall evaluation of all experiences with a company (e.g., Anderson and Narus, 1990), may also act as a mediator. Company-initiated actions may increase the value customers receive from relationships, thereby enhancing satisfaction levels. Satisfied customers not only have more positive experiences to share with others but also remain more committed to companies (Casaló, 2008). This increases their interest in the welfare of companies and the likelihood that they will cooperate and become involved in voluntary helping behaviors. Future research could investigate this issue in further detail. 


\section{References}

Adams, J.S. (1965), “Inequity and social exchange”, Advances in Experimental Social Psychology, Vol. 2, pp. 267-299.

Adelman, M.B. and Ahuvia, A.C. (1995), "Social support in the service sector: the antecedents, processes, and outcomes of social support in an introductory service”, Journal of Business Research, Vol. 32 No. 3, pp. 273-282.

Algesheimer, R., Dholakia, U.M. and Herrmann, A. (2005), “The social influence of brand community: evidence from European car clubs”, Journal of Marketing, Vol. 69 No. 3, pp. 19-34.

Anderson, J.C. and Narus, J.A. (1990), “A model of distributor firm and manufacturer firm working partnerships”, Journal of Marketing, Vol. 54 No. 1, pp. 42-58.

Bartkus, K.R., Howell, R.D., Hills, S.B. and Blackham, J. (2009), “The quality of guest comment cards: an empirical study of U.S. lodging chains”, Journal of Travel Research, Vol. 48 No. 2, pp. 162-176.

Bettencourt, L.A. (1997), “Customer voluntary performance: customers as partners in service delivery”, Journal of Retailing, Vol. 73 No. 3, pp. 383-406.

Bieger, T. and Laesser, T. (2004), “Information sources for travel decisions: toward a source process model”, Journal of Travel Research, Vol. 42 No. 4, pp. 357-371.

Bitner, M.J., Booms, B.H. and Tetreault, M.S. (1990), “The service encounter: diagnosing favorable and unfavorable incidents”, Journal of Marketing, Vol. 54 No. 1, pp. 71-84.

Blau, P.M. (1964), Exchange and Power in Social Life, John Wiley \& Sons, New York.

Brown, T.J., Barry, T.E., Dacin, P.A. and Gunst, R.F. (2005), “Spreading the word: investigating antecedents of consumers' positive word-of-mouth intentions and 
behaviors in a retailing context”, Journal of the Academy of Marketing Science, Vol. 33 No. 2, pp. 123-138.

Casaló, L.V. (2008), “Antecedentes y consecuencias de la participación del consumidor en redes sociales virtuales: El Caso del Sector Turismo”, doctoral thesis, University of Zaragoza, Spain.

Casaló, L.V., Flavián, C. and Guinalíu, M. (2010), “Determinants of the intention to participate in firm-hosted online travel communities and effects on consumer behavioral intentions”, Tourism Management, Vol. 31 No. 6, pp. 898-911.

Casaló, L.V., Flavián, C., Guinalíu, M. and Ekinci, Y. (2015), “Do online hotel rating schemes influence booking behaviors?”, International Journal of Hospitality Management, Vol. 49, pp. 28-36.

Chandon, P., Wansink, B., and Lauren, G. (2000), “A benefit congruency framework of sales promotion effectiveness”, Journal of Marketing, Vol. 64 No. 4, pp. 65-81.

Chin, W.W. (1998), “The partial least squares for structural equation modeling”, in Marcoulides, G.A. (Ed.), Modern Methods for Business Research, Lawrence Erlbaum, Mahwah, NJ, pp. 295-336.

Chin, W.W. (2010), "How to write up and report PLS analyses”, in Esposito, V., Chin, W.W., Henseler, J. and Wang, H. (Ed.), Handbook Of Partial Least Squares, Springer, Berlin Heidelberg, pp. 655-690.

Chin, W.W., Thatcher, J.B. and Wright, R.T. (2012), “Assessing common method bias: problems with the ULMC technique”, MIS Quarterly, Vol. 36 No. 3, pp. 10031019.

Christou, E. (2011), “Exploring Online Sales Promotions in the Hospitality Industry”, Journal of Hospitality Marketing \& Management, Vol. 20 No. 7, pp. 814-829. 
Cohen, J. (1988), Statistical Power Analysis for the Behavioral Sciences, $2^{\text {nd }}$ ed., Lawrence Erlbaum Associates, Hillsdale, NJ.

Confente, I. (2015), “Twenty-five years of word-of-mouth studies: a critical review of tourism research”, International Journal of Tourism Research, Vol. 17 No. 6, pp. 613-624.

Crespo, E. and Del Barrio, S. (2015), “Expert vs. novice users: comparative analysis of the effectiveness of online discounts and gifts”, Revista Española de Investigación de Marketing ESIC, Vol. 19 No.1, pp. 46-61.

Crespo, E. and Del Barrio, S. (2016), “Online airline ticket purchasing: influence of online sales promotion type and Internet experience”, Journal of Air Transport Management, Vol. 53, pp. 23-34.

Davcik, N. (2014), “The use and misuse of structural equation modeling (SEM) in management research: a review and critique”, Journal of Advances in Management Research, Vol. 11 No. 1, pp. 47-81.

DelVecchio, D. (2005), “Deal-prone consumers’ response to promotion: the effects of relative and absolute promotions value”, Psychology \& Marketing, Vol. 22 No. 5, pp. 373-391.

Dijkstra, T.K. and Henseler, J. (2015), “Consistent partial least squares path modeling”, MIS Quarterly, Vol. 39 No. 2, pp. 297-316.

Doob, J., Carlsmith, J., Freedman, J., Landauer, T. and Tom, S. (1969), “Effect of initial selling price on subsequent sales”, Journal of Personality and Social Psychology, Vol. 11 No. 4, pp. 345-350.

Eisenberger, R., Fasolo, P. and Davis-LaMastro, V. (1990), “Perceived organizational support and employee diligence, commitment, and innovation”, Journal of Applied Psychology, Vol. 75 No. 1, pp. 51-59. 
Eisenberger, R., Rhoades, L. and Cameron, J. (1986), “Does pay for performance increase or decrease perceived self-determination and intrinsic motivation?”, Journal of Personality \& Social Psychology, Vol. 77 No. 5, pp. 1026-1040.

Ellerbrock, M.J. (1981), “Improving coupon conversion studies: a comment”, Journal of Travel Research, Vol. 19 No. 4, pp. 37-38.

Fornell, C. and Larcker, D.F. (1981), “Evaluating structural equation models with unobservable variables and measurement error”, Journal of Marketing Research, Vol. 18 No. 1, pp. 39-50.

Gutierrez, J., Camarero, C. and San José, R. (2017), “How brand posts content contributes to user’s Facebook brand-page engagement. The experiential route of active participation”, BRQ Business Research Quarterly, Vol. 20 No. 4, pp. 258-274.

Hair, J.F., Hult, G.T.M., Ringle, C.M. and Sarstedt, M. (2017), A Primer on Partial Least Squares Structural Equation Modeling (PLS-SEM), Sage, Thousand Oaks, CA.

Hassan, M. and Casaló, L. V. (2016), “Consumer devotion to a different height”, Internet Research, Vol. 26 No. 4, pp. 963-981.

Hennig-Thurau, T.F., Gwinner, K.P., Walsh, G. and Gremler, D.D. (2004), “Electronic word-of-mouth via consumer-opinion platforms: what motivates consumers to articulate themselves on the Internet?”, Journal of Interactive Marketing, Vol. 18 No. 1, pp. 38-52.

Henseler, J., Ringle, C. and Sarstedt, M. (2015), “A new criterion for assessing discriminant validity in variance-based structural equation modeling”, Journal of the Academy of Marketing Science, Vol. 43 No. 1, pp. 115-135. 
Hunt, K.A. and Keaveney, S.M. (1994), “A process model of the effects of price promotions on brand image”, Psychology \& Marketing, Vol. 11 No. 6, pp. 511532.

INE (2012), “Encuesta sobre Equipamiento y Uso de Tecnologías de Información y Comunicación en los hogares 2012” [Survey about household usage and equipment for information technologies], available at: http://www.ine.es/jaxi/Datos.htm?path=/t25/p450/base_2011/a2012/10/\&file=04 017.px (accessed 12 August 2017).

Inversini, A. and Masiero, L. (2014), "Selling rooms online: the use of social media and online travel agents”, International Journal of Contemporary Hospitality Management, Vol. 26 No. 2, pp. 272-292.

Keh, H.T. and Teo, C.W. (2001), "Retail customers as partial employees in service provision: a conceptual framework”, International Journal of Retail \& Distribution Management, Vol. 29 No. 8, pp. 370-378.

Kozinets, R.V. (2002), “The field behind the screen: using netnography for marketing research in online communities”, Journal of Marketing Research, Vol. 39 No. 1, pp. 61-72.

Kurtessis, J.N., Eisenberger, R., Ford, M.T., Buffardi, L.C., Stewart, K.A. and Adis, C.S. (2015), "Perceived organizational support: a meta-analytic evaluation of organizational support theory”, Journal of Management, Vol. 43 No. 6, pp. 1854-1884.

Liang, H., Saraf, N., Hu, Q. and Xue, Y. (2007), “Assimilation of enterprise systems: the effect of institutional pressures and the mediating role of top management”, MIS Quarterly, Vol. 31 No. 1, pp. 58-87. 
Litvin, S.W., Goldsmith, R.E. and Pan, B. (2008), "Electronic word-of-mouth in hospitality and tourism management”, Tourism Management, Vol. 29 No. 3, pp. 458-468.

Lo, A.S., Im, H.H, Chen, Y. and Qu, H. (2017), “Building brand relationship quality among hotel loyalty program members”, International Journal of Contemporary Hospitality Management, Vol. 29 No. 1, pp. 458-488.

Magno, F., Cassia, F. and Bruni, A. (2017), “ “Please write a (great) online review for my hotel!” Guests’ reactions to solicited reviews”, Journal of Vacation Marketing, Vol. 24 No. 2, pp. 148-158

Matzler, K., Strobl, A., Stokburger-Sauer, N., Bobovnicky, A. and Bauer, F. (2016), "Brand personality and culture: the role of cultural differences on the impact of brand personality perceptions on tourists' visit intentions”, Tourism Management, Vol. 52, pp. 507-520.

Mudambi, S.M. and Schuff, D. (2010), "What makes a helpful review? A study of customer reviews on Amazon.com”, MIS Quarterly, Vol. 34 No. 1, pp.185-200.

Nunnally, J.C. (1978), Psychometric Theory, $2^{\text {nd }}$ ed., McGraw-Hill, New York.

Parasuraman, A., Zeithaml, V.A. and Berry, L.L. (1985), “A conceptual model of service quality and its implications for future research”, Journal of Marketing, Vol. 49 No. 4, pp. 41-50.

Park, Y.A. and Gretzel, U. (2011), “Travel coupon proneness”, Annals of Tourism Research, Vol. 38 No. 4, pp. 1653-1657.

Pavlou, P.A., Liang, H. and Xue, Y. (2007), “Understanding and mitigating uncertainty in online exchange relationships: a principal-agent perspective”, MIS Quarterly, Vol. 31 No. 1, pp. 105-136. 
Pennington-Gray, L., Beland, R. and Sklar, S. (2002), "Examining the influences of senior discount usage in the hospitality industry”, International Journal of Hospitality and Tourism Administration, Vol. 3 No. 4, pp. 77-93.

Podsakoff, P.M., MacKenzie, S.B., Lee, J.Y. and Podsakoff, N.P. (2003), “Common method biases in behavioral research: a critical review of the literature and recommended remedies”, Journal of Applied Psychology, Vol. 88 No.5, pp. 879903.

Reimers, I. and Xie, C. (2018), “Do Coupons Expand or Cannibalize Revenue?

Evidence from an e-Market”, Management Science, published online on April

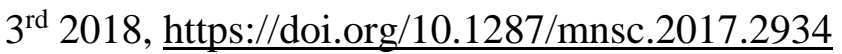

Ringle, C.M., Wende, S. and Becker, J.M. (2015), SmartPLS 3, SmartPLS, Hamburg. Retrieved from http://www.smartpls.com

Romero, J. (2017), “Customer engagement behaviors in hospitality: customer-based antecedents”, Journal of Hospitality Marketing \& Management, Vol. 26 No. 6, pp. 565-584.

Rosenbaum, M.S. and Massiah, C.A. (2007), “When customers receive support from other customers: exploring the influence of intercustomer social support on customer voluntary performance”, Journal of Service Research, Vol. 9 No. 3, pp. 257-270.

Salehi-Esfahani, S., Ravichandran, S., Israeli, A.A. and Bolden E. (2017), “Investigating information adoption tendencies based on restaurants' usergenerated content utilizing a modified information adoption model”, Journal of Hospitality Marketing and Management, Vol. 25 No. 8, pp. 925-953. 
Schmalleger, D. and Carson, D. (2008), "Blogs in tourism: changing approaches to information exchange”, Journal of Vacation Marketing, Vol. 14 No. 2, pp. 99110.

Sigala, M. (2012), “Social networks and customer involvement in new service development (NSD). The case of www.mystarbucksidea.com”, International Journal of Contemporary Hospitality Management, Vol. 24 No. 7, pp. 966-990.

Sigala, M. (2013), “A framework for designing and implementing effective online coupons in tourism and hospitality”, Journal of Vacation Marketing, Vol. 19 No. 2, pp. $165-180$.

Sinha, I. and Smith, M.F. (2000), “Consumers’ attitudes of promotional framing of price”, Psychology \& Marketing, Vol. 17 No. 3, pp. 257-275.

Standing, C., Tang-Taye, J. and Boyer, M. (2014), “The impact of the Internet in travel and tourism: a research review 2001-2010”, Journal of Travel \& Tourism Marketing, Vol. 31 No. 1, pp. 82-113.

Steenhaut, S. and Van Kenhove, P. (2005), "Relationship commitment and ethical consumer behavior in a retail setting: the case of receiving too much change at the checkout”, Journal of Business Ethics, Vol. 56 No. 4, pp. 335-353.

van Doorn, J., Lemon, K.N., Mittal, V., Nass, S., Pick, D., Pirner, P. and Verhoef, P.C. (2010), “Customer engagement behavior: theoretical foundations and research directions”, Journal of Service Research, Vol. 13 No. 3, pp. 253-266.

Verhoef, P.C., Neslin, S.A. and Vroomen, B. (2007), “Multichannel customer management: understanding the research-shopper phenomenon”, International Journal of Research in Marketing, Vol. 24 No.2, pp. 129-148. 
Wasko, M. and Faraj, S. (2005), "Why should I share? Examining social capital and knowledge contribution in electronic networks of practice”, MIS Quarterly, Vol. 29 No. 1, pp. 35-57.

Wilson, A., Murphy, H. and Fierro, J.C. (2012), "Hospitality and travel: the nature and implications of user-generated content”, Cornell Hospitality Quarterly, Vol. 53 No. 3, pp. 220-228.

Yi, Y. and Yoo, J. (2011), “The long-term effects of sales promotions on brand attitude across monetary and non-monetary promotions”, Psychology \& Marketing, Vol. 28 No. 9, pp. 879-896.

Zaichkowsky, J.L. (1985), “Measuring the involvement construct”, Journal of Consumer Research, Vol. 12 No.3, pp. 341-352.

Zhao, H., Liu, Y., Bi, H. and Law, R. (2014), "Influence of coupons on online travel reservation service recovery”, Journal of Hospitality and Tourism Marketing, Vol. 21, pp. 18-26.

Zhao, X., Lynch, J.G. and Chen, Q. (2010), “Reconsidering Baron and Kenny: myths and truths about mediation analysis”, Journal of Consumer Research, Vol. 37 No. 2, pp. 197-206. 
Figure 1. Estimation results

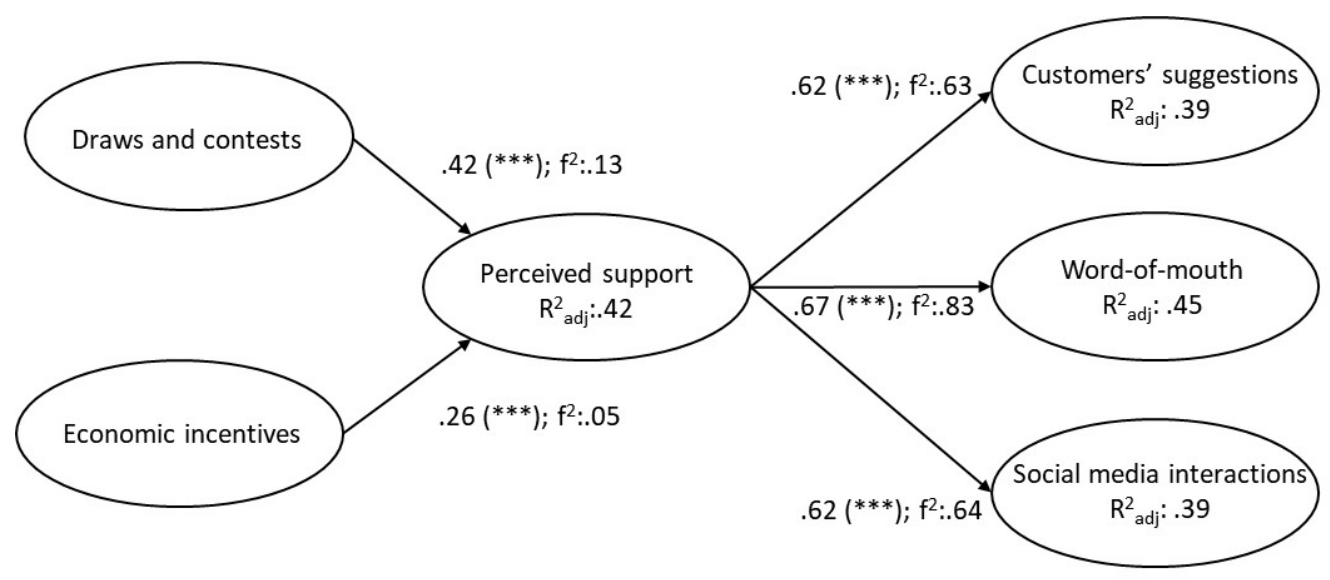

$* * *$ : significant at a $99 \%$ level 
Table 1. Measurement items, construct reliability and convergent validity

\begin{tabular}{|c|c|c|c|c|}
\hline & Mean & SD & $\begin{array}{c}\text { Excess } \\
\text { Kurtosis } \\
\end{array}$ & Skewness \\
\hline \multicolumn{5}{|l|}{$\begin{array}{l}\text { Draws and contests (adapted from Hennig-Thurau et al., 2004) } \\
\alpha=0.96 ; \mathrm{CR}=0.96 ; \mathrm{AVE}=0.88 .\end{array}$} \\
\hline I participate in the draws that this OTA organizes at social networks. & 4.45 & 1.47 & -0.55 & -0.16 \\
\hline I participate in the contests that this OTA organizes at social networks. & 4.43 & 1.44 & -0.41 & -0.20 \\
\hline I find attractive this OTA’ activities in which I can win a prize. & 4.55 & 1.45 & -0.42 & -0.33 \\
\hline \multicolumn{5}{|l|}{$\begin{array}{l}\text { Economic incentives (adapted from Hennig-Thurau et al., 2004) } \\
\alpha=0.75 ; \mathrm{CR}=0.75 ; \mathrm{AVE}=0.60\end{array}$} \\
\hline This OTA offers important discounts to me at social networks. & 5.05 & 1.40 & -0.30 & -0.47 \\
\hline In general, I visit this OTA because it gives me economic rewards at social networks. & 4.43 & 1.47 & -0.45 & -0.21 \\
\hline \multicolumn{5}{|l|}{$\begin{array}{l}\text { Perceived support (adapted from Bettencourt, 1997) } \\
\alpha=0.97 ; \mathrm{CR}=0.97 ; \mathrm{AVE}=0.60 \text {. }\end{array}$} \\
\hline This OTA cares about my opinions. & 4.80 & 1.24 & -0.09 & -0.30 \\
\hline This OTA strongly considers my needs and wants. & 4.52 & 1.39 & -0.54 & -0.10 \\
\hline This OTA appreciates my comments and suggestions & 4.60 & 1.33 & -0.33 & -0.22 \\
\hline This OTA values my contribution to improve its services & 4.61 & 1.35 & -0.48 & -0.19 \\
\hline This OTA is willing to help me when I have a special request. & 4.88 & 1.25 & -0.07 & -0.36 \\
\hline Help is available from this OTA when I have a problem. & 4.90 & 1.25 & -0.16 & -0.32 \\
\hline This OTA would not ignore any complaint from me. & 4.94 & 1.25 & -0.19 & -0.24 \\
\hline This OTA tries to provide the best service possible. & 5.23 & 1.10 & -0.29 & -0.26 \\
\hline This OTA cares about my general satisfaction. & 5.09 & 1.16 & -0.28 & -0.22 \\
\hline This OTA would never take advantage of me. & 4.74 & 1.28 & -0.36 & -0.18 \\
\hline This OTA takes into account my interests when it makes decisions that affect me. & 4.82 & 1.23 & -0.15 & -0.28 \\
\hline This OTA really cares about my well-being. & 4.71 & 1.30 & -0.34 & -0.28 \\
\hline This OTA shows concern for me. & 4.52 & 1.36 & -0.41 & -0.25 \\
\hline I am not just another customer to this OTA. & 4.21 & 1.54 & -0.58 & -0.21 \\
\hline \multicolumn{5}{|l|}{$\begin{array}{l}\text { Customers' suggestions (adapted from Bettencourt, 1997) } \\
\alpha=0.92 ; \mathrm{CR}=0.92 ; \mathrm{AVE}=0.69 .\end{array}$} \\
\hline I let this OTA know of ways that they can better serve my needs. & 4.54 & 1.54 & -0.42 & -0.33 \\
\hline I make constructive suggestions to this OTA about how to improve its service. & 4.28 & 1.63 & -0.66 & -0.22 \\
\hline If I have a useful idea of how to improve service, I give it to someone at this OTA. & 4.16 & 1.66 & -0.74 & -0.16 \\
\hline $\begin{array}{l}\text { When I experience a problem at this OTA, I let someone know so it can improve the } \\
\text { service. }\end{array}$ & 4.68 & 1.51 & -0.23 & -0.41 \\
\hline If I notice a problem, I inform this OTA even if it does affect me. & 4.20 & 1.54 & -0.49 & -0.21 \\
\hline \multicolumn{5}{|l|}{ WOM (adapted from Brown et al, 2005) } \\
\hline I mention to others that I do business with this OTA. & 4.62 & 1.45 & -0.40 & -0.29 \\
\hline I make sure that others know that I do business with this OTA. & 4.20 & 1.54 & -0.61 & -0.10 \\
\hline I recommended this OTA to family members. & 4.84 & 1.35 & -0.06 & -0.40 \\
\hline I speak positively of this OTA to others. & 4.89 & 1.36 & -0.06 & -0.50 \\
\hline I recommend this OTA to acquaintances. & 4.91 & 1.38 & -0.12 & -0.50 \\
\hline I recommended this OTA to close friends. & 5.01 & 1.38 & -0.04 & -0.56 \\
\hline \multicolumn{5}{|l|}{$\begin{array}{l}\text { Social media interactions (adapted from Casaló, 2008) } \\
\alpha=0.92 ; \mathrm{CR}=0.91 ; \mathrm{AVE}=0.68\end{array}$} \\
\hline $\begin{array}{l}\text { I assess and share with other users my opinions and experiences about the products and } \\
\text { services of this OTA on the company website. }\end{array}$ & 4.21 & 1.59 & -0.62 & -0.24 \\
\hline I write comments in the blog and/or in the profile of this OTA in social networks (e.g., & & & & \\
\hline Facebook, Twitter, etc.). & 3.64 & 1.69 & -0.97 & 0.12 \\
\hline I write comments in the forums on this OTA. & 3.59 & 1.73 & -1.04 & 0.17 \\
\hline When I find an interesting content at this OTA I say it at SNS & 4.04 & 1.71 & -0.97 & 0.01 \\
\hline I follow this OTA through SNS & 4.02 & 1.79 & -1.00 & -0.05 \\
\hline
\end{tabular}

Note: All items are measured with a 7-point Likert scale anchoring strongly disagree (1) and strongly agree (7). $\alpha=$ Cronbach's alpha, $\mathrm{CR}=\mathrm{CR}, \mathrm{AVE}=$ average variance extracted, $\mathrm{M}=$ mean, $\mathrm{SD}=$ standard deviation. 
Table 2. Discriminant validity analysis: Fornell \& Larcker criterion and HTMT

\begin{tabular}{|c|c|c|c|c|c|c|}
\hline Fornell \& Larcker criterion * & (1) & (2) & (3) & (4) & (5) & (6) \\
\hline Draws and contests (1) & 0.9404 & & & & & \\
\hline Economic incentives (2) & 0.7678 & 0.7749 & & & & \\
\hline Perceived support (3) & 0.6246 & 0.5882 & 0.8172 & & & \\
\hline Customers’ suggestions (4) & 0.5984 & 0.4689 & 0.6219 & 0.8323 & & \\
\hline WOM (5) & 0.5864 & 0.7402 & 0.6740 & 0.6528 & 0.8838 & \\
\hline Social media interactions (6) & 0.6539 & 0.5732 & 0.6242 & 0.8040 & 0.6666 & 0.8238 \\
\hline \multicolumn{7}{|l|}{ HTMT } \\
\hline & (1) & (2) & (3) & (4) & (5) & (6) \\
\hline \multicolumn{7}{|l|}{ Draws and contests (1) } \\
\hline Economic incentives (2) & .7706 & & & & & \\
\hline Perceived support (3) & .6249 & .5905 & & & & \\
\hline Customers' suggestions (4) & .5980 & .4740 & .6220 & & & \\
\hline WOM (5) & .5868 & .7431 & .6750 & .6604 & & \\
\hline Social media interactions (6) & 6535 & .5736 & 6187 & .8042 & .6671 & \\
\hline
\end{tabular}

Table 3. Indirect and direct effects

\begin{tabular}{|c|c|c|}
\hline & Estimate & $\begin{array}{l}\text { 95\% Bias corrected } \\
\text { and accelerated } \\
\text { confidence interval }\end{array}$ \\
\hline \multicolumn{3}{|l|}{ Research model: draws and contests } \\
\hline Indirect effect draws and contests --> customers' suggestions & 0.26 & $(0.15,0.37)$ \\
\hline Indirect effect draws and contests --> WOM & 0.28 & $(0.17,0.39)$ \\
\hline Indirect effect draws and contests --> Social media interactions & 0.42 & $(0.24,0.57)$ \\
\hline \multicolumn{3}{|l|}{ Research model: economic incentives } \\
\hline Indirect effect economic Incentives --> customers’ suggestions & 0.26 & $(0.15,0.37)$ \\
\hline Indirect effect economic Incentives --> WOM & 0.16 & $(0.06,0.29)$ \\
\hline Indirect effect economic Incentives --> Social media interactions & 0.18 & $(0.06,0.31)$ \\
\hline \multicolumn{3}{|l|}{ Extended research model: draws and contests } \\
\hline Direct effect draws and contests --> customers’ suggestions & 0.40 & $(0.20,0.58)$ \\
\hline Indirect effect draws and contests --> customers' suggestions & 0.18 & $(0.1,0.27)$ \\
\hline Direct effect draws and contests --> WOM & -0.13 & $(-0.34,0.03)$ \\
\hline Indirect effect draws and contests --> WOM & 0.17 & $(0.08,0.26)$ \\
\hline Direct effect draws and contests --> Social media interactions & 0.38 & $(0.22,0.51)$ \\
\hline Indirect effect draws and contests --> Social media interactions & 0.14 & $(0.08,0.22)$ \\
\hline \multicolumn{3}{|l|}{ Extended research model: economic Incentives } \\
\hline Direct effect economic Incentives --> customers’ suggestions & -0.09 & $(-0.29,0.13)$ \\
\hline Indirect effect economic Incentives --> customers' suggestions & 0.11 & $(0.04,0.21)$ \\
\hline Direct effect economic Incentives --> WOM & 0.61 & $(0.43,0.86)$ \\
\hline Indirect effect economic Incentives --> WOM & 0.11 & $(0.04,0.18)$ \\
\hline Direct effect economic Incentives --> Social media interactions & 0.09 & $(-0.07,0.26)$ \\
\hline Indirect effect economic Incentives --> Social media interactions & 0.09 & $(0.03,0.17)$ \\
\hline
\end{tabular}

